\title{
Extraordinary Legal Remedies By the Prosecutor in Criminal Procedure
}

\section{Indi Premadasa*) and Akhmad Khisni*)}

*) Student of Master of Law, Faculty of Law, Universitas Islam Sultan Agung Semarang, E-mail: premadasa2305@gmail.com

*) Faculty of Law, Universitas Islam Sultan Agung Semarang

\begin{abstract}
The purpose of this study is to study and analyze the judicial review of the prosecutors in criminal procedural law. In this paper the author uses the normative juridical method. In the discussion that the public prosecutor has the right to file a basic review of Article 263 paragraph (2) and (3) of the Criminal Procedure Code, apart from Article 263 of the Criminal Procedure Code, the Public Prosecutor has a basis for laws and regulations relating to the issue of reconsideration, namely Article 21 Act No. 14 of 1970 concerning the basic provisions of judicial power, Article 24 of Act No. 48 of 2009 concerning Judicial Power, apart from the statutory regulations mentioned above, the Public Prosecutor filed a Reconsideration on the principles of justice and the principle of balance.
\end{abstract}

Keywords: Legal Effort; Reconsideration; Public Prosecutor.

\section{Introduction}

Law enforcement is one of the means to create an orderly national and state life in order to create justice and prosperity for all Indonesian people. ${ }^{1}$ In order to guarantee the realization of just law enforcement for every citizen, the 1945 Constitution of the Republic of Indonesia (UUD NRI 1945) has clearly stated that the Indonesian State is based on law (rechtstaat) not based on mere power (machsstaat). ${ }^{2}$ This provision can be found in the explanation of the 1945 Constitution of the Republic of Indonesia, namely Article 1 paragraph (3) which states that "the State of Indonesia is a State of Law".

According to R. Subekti, as stated by Marwan Effendy, the legal system is an orderly arrangement, a whole consisting of parts that are related to one another, arranged according to a plan or pattern, the result of a thought, to achieve a destination. ${ }^{3}$ Meanwhile, Sudikno Mertokusumo stated that the legal system is a unit consisting of elements that interact with each other and work together to achieve the goal of this unity. ${ }^{4}$

\footnotetext{
${ }^{1}$ Alvi Syahri. Law Enforcement against Policies Who Breached the Code of Conduct, Jurnal Daulat Hukum, Vol.3 No.3, September $2020 . \quad$ url: http://jurnal.unissula.ac.id/index.php/RH/article/view/11238/4399.

${ }^{2}$ I Dewa Putu Gede Anom Danujaya, and Sri Endah Wahyuningsih. Legal Policy On The Existence of Criminal Law Of Illegal Foreign Labor In Indonesia. Jurnal Daulat Hukum, Vol. 2 No. 2, June 2019, url: http://jurnal.unissula.ac.id/index.php/RH/article/view/5412/3340.

${ }^{3}$ Marwan Effendy. (2005). Kejaksaan RI: Posisi dan Fungsinya dari Perspektif Hukum. Jakarta: PT Gramedia Pustaka Utama. p. 99.

${ }^{4}$ Ibid
} 
The legal system according to Lawrence M Friedman, consists of 3 (three) elements that influence each other, namely: legal substance, legal structure, and legal culture. ${ }^{5}$ In a rule of law, the system used to solve various criminal problems that occur in social life is a criminal justice system. ${ }^{6}$ The term criminal justice system was first introduced by criminal law experts in the United States as a reaction to the failure of the working mechanism of law enforcement officials and law enforcement agencies in reducing the crime rate. This failure led to the emergence of the idea of the need for a "system approach" in the criminal justice administration mechanism. This approach, in criminology and crime prevention theory is known as a "criminal justice system model".7

In a criminal justice system, a court decision can be said to have obtained permanent legal force ${ }^{8}$ (in kracht van gewijsde), in the current criminal procedure law (KUHAP) and in Government Regulation Number 27 of 1983 concerning the Implementation of the Criminal Procedure Code, do not regulate it at all. However, in the Decree of the Minister of Justice Number M.14-PW.07.03 of 1983 concerning Additional Guidelines for the Implementation of the Criminal Procedure Code, it is stated that a new court decision is declared to have permanent legal force if the time limit for thinking has been exceeded 7 (seven) days after the first level court decision and 14 (fourteen) days after the decision of the appellate court. ${ }^{9}$

In connection with the notion of reconsideration, there is no specific definition that provides this definition, Andi Hamzah provides the definition of reconsideration as the right of the convict to ask to correct a court decision that has become permanent, as a result of a judge's mistake or negligence in making his decision. ${ }^{10}$ Meanwhile, Adami Chazawi stated that the reconsideration was an extraordinary legal effort to oppose the fixed punishment decision and could only be submitted by the convict or his heirs. ${ }^{11}$

In legal practice, the formulation of Article 263 of the Criminal Procedure Code has generated controversial opinions and polemics among practitioners, academics and law enforcement officials. Some of them stated that only the convict or their heirs were entitled to apply for a judicial review (PK). This opinion is based on Article 263 paragraph (1) of the Criminal Procedure Code. Where as

\footnotetext{
${ }^{5}$ Lawrence M Friedman. (2001). American Law An Introduction, $2^{\text {nd }}$ Edition. (Hukum Amerika: Sebuah Pengantar, Penterjemah Wisnu Basuki). Jakarta: Tata Nusa. p. 7-8.

${ }^{6}$ Vitriano Aditya Morradi, and Munsharif Abdul Chalim. Criminal Law Enforcement Policies In Prevention Efforts Of Information Technology Crime. Jurnal Daulat Hukum, Vol.2 No.2, June 2019. url: http://jurnal.unissula.ac.id/index.php/RH/article/view/5545/3375.

${ }^{7}$ Cristina Soerya. (2001). Kedudukan Kejaksaan Agung Sebagai Penegak Hukum Dalam Sistem Peradilan Pidana. Jakarta: Puslitbang Kejaksaaan Agung RI. p.11.

${ }^{8}$ Wilmar Ibni Rusydan, Umar Ma'ruf, and Bambang Tri Bawono. Judicial Activism In Criminal Case To Ensure The Human Rights Upholding (Study In State Court Of Semarang), Jurnal Daulat Hukum, Vol.2 No.4, December $2019 . \quad$ url: http://jurnal.unissula.ac.id/index.php/RH/article/view/8347/3868.

${ }^{9}$ Ahmad Fauzi. Analisis Yuridis Terhadap Upaya Hukum Luar Biasa Peninjauan Kembali (PK) Oleh Jaksa Dalam Sistem Hukum Acara Pidana Indonesia. Jurnal Hukum, Vol.4 No.2, February-July 2014. p. 142.

${ }^{10}$ Andi Hamzah, and Irdan Dahlan. (1987). Upaya Hukum Dalam Perkara Pidana. Bina Aksara. p.4.

${ }^{11}$ Adami Chazawi. (2010). Lembaga Peninjauan Kembali (PK) Perkara Pidana, Penegakan Hukum dalam Penyimpangan Praktik \& Peradilan Sesat. Jakarta: Sinar Grafika. p. 1.
} 
according to the actual fact Article 263 consists of 3 (three) paragraphs, namely paragraph (1) regulating the rights of the convicted person or his heirs to apply for a Judicial Review, paragraph (2) adheres to the basic reasons or requirements for filing a review and paragraph (3) which is often forgotten and considered nonexistent by some practitioners, namely regulating the rights of other parties who are not convicted or their heirs. The party that is not explicitly stated only has the right in the sense of being able to file a judicial review if there is a court ruling stating that the accused is deemed proven but not followed by a criminal conviction. Since there is no conviction in the verdict, the decision referred to in Article 263 paragraph (3) is clearly not a convict, but another party dealing with the convicted person, namely the Public Prosecutor (JPU). Thus it can be concluded that there are two parties entitled to apply for a Judicial Review based on Article 263 of the Criminal Procedure Code, namely the convicted party or his heirs (Article 263 paragraph (1) KUHAP) and the Public Prosecutor (Article 263 paragraph (3) KUHAP). ${ }^{12}$

Based on the above background, this study aims to determine and analyze reconsideration by the prosecutor in criminal procedural law?

\section{Research Methods}

This research uses the normative juridical method, with an emphasis on literature study. As a normative-based juridical writing, this writing is based on an analysis of legal norms, both law in the sense of law as it is written in the books (in statutory rules) and law in the sense of decided by judge thought judicial process (court decisions). Thus, the object to be analyzed is legal norms, both in statutory regulations and those that have been concretely stipulated by the judge in cases decided in court.

\section{Result and Discussion}

\section{Judicial Review by Prosecutors in Criminal Procedure Law}

As is well known, the function of criminal procedure law is to seek and obtain or at least approach the complete truth of a criminal case so that the application of criminal law can be precisely and honestly to a person or group who commits the criminal act, ${ }^{13}$ Van Bemellen even more explicitly stated that the function of criminal procedural law is to seek the truth, provide certainty by judges, and enforce decisions. ${ }^{14}$ Broadly speaking, the provision of legal certainty is the main foundation in the implementation of criminal procedural law itself, so that the judge's decision to be taken is the right decision which will then be carried out (execution) by the prosecutor so as to create order, tranquility, peace, justice and prosperity in Public. ${ }^{15}$

\footnotetext{
12 HMA Kuffal. (2010). Penerapan KUHAP Dalam Praktik Hukum. Malang: UMM Press. p. 294-295.

13 Daliyo. (2001). Pengantar Hukum Indonesia. Jakarta: Prehallindo. p. 221.

${ }^{14}$ Andi Hamzah. (2006). Hukum Acara Pidana Indonesia. Jakarta: Sinar Grafika. p. 8-9.

15 Ibid
} 
Although currently the Criminal Procedure Code is more than 30 years old, the enactment of Article 263 of the Criminal Procedure Code regulates extraordinary legal remedies called reconsiderations (PK) in its implementation, which still raises a counter-opinion. Because in reality there are still some experts, practitioners and legal observers who argue that those who can apply for a PK are the convicted person or their heir of Article 263 paragraph (1) of the Criminal Procedure Code, while the public prosecutor is actually acting for and on behalf of the state and at the same time representing the crime victim is considered not has the right to file a legal remedy for judicial review. ${ }^{16}$

If we read and understand it completely and not interpreted in pieces the contents of Article 263 of the Criminal Procedure Code, until now there are still some parties who argue that only the convict or his heirs are entitled to apply for PK, while the public prosecutor who in fact represents the community and victims of crime. deemed not eligible to apply for PK.

A part from being unfair, this opinion is not based on a complete and objective interpretation of Article 263 of the Criminal Procedure Code. Based on the sound of Article 263 paragraph (1) and (2) of the Criminal Procedure Code, it is expressly stated that those who can apply for PK are the convict or his heirs. However, based on "article 263 paragraph (3) of the Criminal Procedure Code", it turns out that apart from the "convicted" or "heir" there are still other parties who can submit legal remedies for judicial review (PK), namely the other party is not explicitly mentioned but the other party is not another is the public prosecutor, against a court decision that has obtained the power of inckracht which in its dictum or which reads states "the act accused has been proven but has not been followed by a conviction". ${ }^{17}$ In other words, in the verdict the defendant is not subject to law or a criminal verdict even though the defendant has been found guilty or guilty, therefore in this case the public prosecutor has the right to file a PK, the convict has been found guilty but still not sentenced.

The right of the prosecutor to file a legal remedy for formal legal review is not regulated in Act No. 8 of 1981 concerning KUHAP, but the public prosecutor to make legal remedies is only regulated in legal remedies, appeals and cassations (for legal purposes, Article 259 paragraph (1) KUHAP and Article 35 letter d Act No. 16 of 2004 concerning the RI Prosecutor's Office) for the PK itself is not legally regulated, but in practice the public prosecutor has the right to file a review for the public interest, the state, the victim and the parties. Third, indeed in the Criminal Procedure Code for the rights of victims and third parties it is not given space or is not regulated in the KUHAP, therefore the public prosecutor has the right to file a PK even though in formal law the public prosecutor is not allowed to,however, on the basis of justice and balance, the public prosecutor has the same rights as the convict or his heirs.

The formulation of Article 263 paragraph (3) of the Criminal Procedure Code can be seen that apart from the convict or his heirs, it turns out that there are other parties who can apply for PK, even though the other party is not explicitly stated. Since in the criminal court proceedings there are only two parties facing

16 HMA Kuffal. (2010). Op.Cit. p. 232.
17 Ibid 
each other, namely the public prosecutor and the defendant (with or his legal advisor), it can be easily concluded that the other party is the party facing the defendant, namely the public prosecutor (JPU). Therefore, the public prosecutor has the same rights as the convicted person or their expert in filing a PK and in the name of justice, the prosecutor as the state's representative, the victim and other interested parties.

Article 263 of the Criminal Procedure Code, which consists of three verses, is read in full and objectively so that it can produce conclusions that are in accordance with the sense of justice and human rights, both human rights owned by the convict or his heirs as well as human rights owned by crime victims or third parties who are involved in the process of representing by the public prosecutor. And to further strengthen the formulation of Article 263 paragraph (3) of the Criminal Procedure Code, it is necessary to compare it with the formulation of Article 248 paragraph (3) of Act no. 31 of 1997 concerning Military Criminal Procedure Law. Article 248 paragraph (3) of Act No. 31 of 1997 concerning Military Criminal Procedure Law can be said to be almost the same as the content of Article 263 paragraph (3) of the Criminal Procedure Code.

Besides that, in article 27 paragraph (1) of the 1945 Constitution of the Republic of Indonesia, it can be interpreted that every citizen (every person) apart from having the obligation to uphold the law and government, without exception whether they have the status as a suspect or defendant or the status as a victim. all crimes have the same position, dignity and human rights for justice seekers in general. ${ }^{18}$

In connection with the extraordinary legal remedies for the review, an event has been very interesting and can be said to be a historic event, because since the enactment of the Criminal Procedure Code on December 31, 1981. The public prosecutor can file a PK by making a legal breakthrough as happened in the convict's case. Muchtar Pakpahan, who by the Medan District Court sentenced him to 3 (three) years in prison and by the North Sumatra High Court at the appeal level, the defendant was sentenced to 4 (four) years in prison. Even though at the cassation level the defendant was acquitted of all lawsuits or charges, on the PK application submitted by the public prosecutor, and on 25 October 1996 with Number 55 PK/PID/1996 has canceled Muchtar Pakpakhan's verdict for 4 (four) years imprisonment. The Supreme Court's PK decision is a historical event in law enforcement in the Republic of Indonesia because the PK decision submitted by the public prosecutor is a legal breakthrough made by the public prosecutor and the Supreme Court accepts the PK submitted by the public prosecutor. ${ }^{19}$

In the formation of the provisions of Article 263 paragraph (3) of the Criminal Procedure Code which explicitly or formally do not explain that the prosecutor can apply for the PK, it can selectively make the legal basis as the prosecutor to file a PK in the future for the sake of upholding justice and truth.

The legal basis used by the public prosecutor to file a review is Article 263 paragraphs (1), (2) and (3) KUHAP, Act No. 49 of 2009 concerning Judicial Power,

\footnotetext{
18 HMA Kuffal. (2010). Op.Cit. p. 235.

${ }^{19}$ Yading Ariyanto. (2015). Hak Jaksa Penuntut Umum Mengajukan Peninjauan Kembali Dalam Perspektif Keadilan Hukum di Indonesia. Universitas Brawijaya: Magister Ilmu Hukum. p. 10.
} 
Act No. 14 of 1970 Concerning the Principles of Power judiciary of the Republic of Indonesia, Act No. 19 of 1964 concerning the basic provisions of judicial power, Act No. 13 of 1965 concerning courts within the general judiciary and MA, and the Ghandi Memorial School are the basis for consideration of prosecutors proposing PK and making Jurisprudence. ${ }^{20}$

The substance of the PK is based on the basis that the state has wrongly convicted an innocent population and cannot be corrected by ordinary legal remedies but must be done with extraordinary legal remedies, namely PK, but according to the author, in applying for PK, it is not only intended for the convict or his heirs. but also to prosecutors, on the basis of justice and the principle of balance, if we look closely at the contents of Article 263 paragraph (3) of the Criminal Procedure Code, people who have been proven guilty but not followed by a punishment, which means that people who have been proven guilty are not followed by this criminal act. which is unfair, because a person who has been proven guilty but has not been subject to punishment, is an error or mistake by a judge. Therefore, it is natural for the public prosecutor to file a PK against a criminal act.

The PK legal remedies filed by the prosecutor cause many pros and cons among academics, legal practitioners and legal experts where each of them has a different view from one another, some say that PK is the right of the convict or his heirs based on Article 263 paragraph (1) The Criminal Procedure Code is not the right of the public prosecutor, but some say that the prosecutor has the same rights as the convicted person based on Article 263 paragraph (2) and paragraph (3) KUHAP and Act No. 48 of 2009 concerning judicial power in particular. Article 10 paragraph (1) and Article 24 paragraph (1), from this legal basis, if the contents of the article are examined both in the Criminal Procedure Code and Act No. 48 of 2009 concerning Judicial Power, the prosecutor has the same position as the convicted person, that is, they can apply for a PK. ,The first PK filed by the prosecutor was in the Muchtar Pakpahan case at the Muchtar Pakpahan District Court level was convicted by the Medan first instance court, and at the high court upheld the first instance court's decision, but at the cassation level Muchtar Pakpahan was acquitted because he was not proven. From the beginning of Muchtar Pakphan's case, the public prosecutor submitted a PK because on a strong basis to achieve a sense of justice, because according to the prosecutor's view that the judge made a mistake and made a real mistake in giving a decision and the existence of a new means of evidence (novum), as well as on the basis of justice then from The prosecutor has the same right to apply for a PK. ${ }^{21}$

\section{Closing}

The public prosecutor has the right to file a basic review of Article 263 paragraph (2) and (3) of the Criminal Procedure Code, apart from Article 263 of the KUHAP, the prosecutor has a basis for laws and regulations relating to the issue of reconsideration, namely Article 21 of Act No. 14 of 1970 regarding the basic

\footnotetext{
${ }^{20}$ Mochtar Kusumaatmadja. (2006). Konsep-Konsep Hukum dalam Pembangunan. Kumpulan Karya Tulis. p. 20.

${ }^{21}$ Ibid. p. 11
} 
provisions of judicial power, Article 24 of Act No. 48 of 2009 concerning Judicial Power, apart from the statutory regulations mentioned above, the Prosecutor proposes a PK on the basis of the principles of justice and the principle of balance. receiving a review from the prosecutor is a legal breakthrough made by the prosecutor and used as jurisprudence for other prosecutors in filing a judicial review.

Based on the description above it is suggested that The judicial review decision by the public prosecutor should delve deeper into the objectives of the law. Not only focus on fairness in proportional equality, but also must pay attention to corrective justice. So that the rights of the convict must also be fulfilled. This is intended so that the State is not arbitrary, so that legal certainty can arise. Extraordinary legal measures should be used by the Attorney General, and for legal purposes. In this case it is contained in Article 259 paragraph (1) and paragraph (2) of the Criminal Procedure Code. For the public interest itself is First, when the suspect or defendant dies. Second, the case is ne bis in idem, a legal principle that prohibits a defendant from being tried more than once for an act if there is already a verdict that punishes or acquits him. Third, the case has expired by referring to Article 78 of the Criminal Code. Referring to the explanation above, it is possible for the Public Prosecutor to submit a Judicial Review in the Interest of Law.

\section{References}

\section{Journals:}

[1] Ahmad Fauzi. Analisis Yuridis Terhadap Upaya Hukum Luar Biasa Peninjauan Kembali (PK) Oleh Jaksa Dalam Sistem Hukum Acara Pidana Indonesia. Jurnal Hukum, Vol.4 No.2, February-July 2014.

[2] Alvi Syahri. Law Enforcement against Policies Who Breached the Code of Conduct. Jurnal Daulat Hukum, Vol.3 No.3, September 2020. url: http://jurnal.unissula.ac.id/index.php/RH/article/view/11238/4399.

[3] I Dewa Putu Gede Anom Danujaya, and and Sri Endah Wahyuningsih. Legal Policy On The Existence Of Criminal Law Of Illegal Foreign Labor In Indonesia. Jurnal Daulat Hukum, Vol.2 No.2, June 2019, url: http://jurnal.unissula.ac.id/index.php/RH/article/view/5412/3340.

[4] Vitriano Aditya Morradi, and Munsharif Abdul Chalim. Criminal Law Enforcement Policies In Prevention Efforts Of Information Technology Crime. Jurnal Daulat Hukum, Vol.2 No.2, June 2019, url: http://jurnal.unissula.ac.id/index.php/RH/article/view/5545/3375.

[5] Wilmar Ibni Rusydan, Umar Ma'ruf, and Bambang Tri Bawono, Judicial Activism In Criminal Case To Ensure The Human Rights Upholding (Study In State Court Of Semarang). Jurnal Daulat Hukum, Vol.2 No.4, December 2019, url: http://jurnal.unissula.ac.id/index.php/RH/article/view/8347/3868

\section{Books:}

[1] Adami Chazawi. (2010). Lembaga Peninjauan Kembali (PK) Perkara Pidana, Penegakan Hukum dalam Penyimpangan Praktik \& Peradilan Sesat. Jakarta: Sinar Grafika. 
[2] Andi Hamzah and Irdan Dahlan. (1987). Upaya Hukum Dalam Perkara Pidana. Jakarta: Bina Aksara.

[3] Andi Hamzah. (2006). Hukum Acara Pidana Indonesia. Jakarta: Sinar Grafika.

[4] Cristina Soerya. (2001). Kedudukan Kejaksaan Agung Sebagai Penegak Hukum Dalam Sistem Peradilan Pidana. Jakarta: Puslitbang Kejaksaaan Agung RI.

[5] Daliyo. (2001). Pengantar Hukum Indonesia. Jakarta: Prehallindo.

[6] HMA Kuffal. (2010). Penerapan KUHAP Dalam Praktik Hukum. Malang: UMM Press.

[7] Lawrence M Friedman. (2001). American Law An Introduction, 2nd Edition. (Hukum Amerika: Sebuah Pengantar, Penterjemah Wisnu Basuki). Jakarta: Tata Nusa.

[8] Marwan Effendy. (2005). Kejaksaan RI: Posisi dan Fungsinya dari Perspektif Hukum, Jakarta: PT Gramedia Pustaka Utama.

[9] Mochtar Kusumaatmadja. (2006). Konsep-Konsep Hukum dalam Pembangunan. Kumpulan Karya Tulis

[10] Yading Ariyanto. (2015). Hak Jaksa Penuntut Umum Mengajukan Peninjauan Kembali Dalam Perspektif Keadilan Hukum di Indonesia. Universitas Brawijaya: Magister Ilmu Hukum. 